\title{
The Readiness of Lecturers in Embedding Soft Skills in the Bachelor's Degree Program in Malaysia's Teachers Education Institute
}

\author{
Aminuddin Hassan, Marina Maharoff and Norhasni Zainal Abiddin*
}

Department of Professional Development and Continuing Education, Faculty of Educational Studies, University Putra Malaysia, Malaysia

\begin{abstract}
This is a preliminary research to obtain information to formulate a problem statement for an overall study of the embedding of soft skills in the program courses in higher learning institutions. This research was conducted in the form of single case and multi-case studies. The research data was attained through mixed methods; the quantitative method by utilizing questionnaires and the qualitative method utilizing open-ended questionnaires. Qualitative data were used as supporting data in this research. This research sought to study two main issues; the readiness of lecturers and problems encountered in embedding soft skills into teachers' bachelor's degree courses in Malaysia's Institute of Teachers Education. Quantitative data was processed manually to show frequency, while qualitative data was processed according to themes. Research findings indicated that a majority of lecturers are interested and ready to embed soft skills in the core courses. However, lecturers lamented about problems encountered in embedding soft skills in teaching and learning of courses even though the curriculum of the programs have been designed holistically to fulfill the needs to develop soft skills within trainee teachers.
\end{abstract}

\section{Introduction}

Perreault [1] defined soft skills as a personal quality, attribute or level of one's commitment which sets apart individuals with the same skill and experience. James and James [2] concurred that soft skills is a new trend in explaining a set of ability or talent which could be utilized at a workplace. Soft skills has the ability to categorize specific career attribute which an individual has such as team spirit, communication skills, leadership skills, customer service skills and problem solving skills. "Employers Value Communication and Interpersonal Skills" in Mitchell et al. [3] states that a person who communicates effectively, adapts well with others, works well in a team, takes initiative and has a formidable work ethics is considered as having the required level of set soft skills. Sutton [4] considered soft skills as instrumental to the point that many employers feel that soft skills can be used to set apart job applicants in most industries. Glenn [5] additionally feels that hiring a person with soft skills is crucial as it promotes competitiveness in highprestige organizations. Wilhelm [6] agrees and asserts that employers consider soft skills acquisition as extremely vital to be successful in the workplace. In teachers' training context, soft skills has now an important elements which needs to be developed among trainee teachers as it promotes teachers as social capital who are able to balance outward and inward emotions and are intellectually and spiritually able to navigate future challenges in the teaching career.

However, there are still research findings which concluded that when a trainee teachers becomes a full-fledge teacher, they will still need three to four years to acquire competency and a few more years to become a professional [7]. A research conducted by Muhammad Sidek [8] proved that when the efficacy of teachers are evaluated by school administrators based on quality indicators, teaching and learning, co-curriculum execution and school management, emerging teachers scored minimally or slightly above average when appraised according to standards set by Department of Teacher Education. Among problems discovered is the inefficacy of training that teachers underwent to create teachers who could cohesively blend internal, external, emotional aspects with intellectual aspects [9-11]. This begs the question: Why is the efficacy of teachers still low when soft skills development has long been introduced into teachers' bachelor's degree course in Malaysia's Institute of Teachers Education?

\section{Purpose of Study}

The purpose of this study is to obtain preliminary information about the readiness of lecturers and the problems they encounter in embedding soft skills in the courses they teach. This research is important to researchers and individuals who are involved in developing soft skills for trainee teachers because reported findings will aid in the process of understanding the needs to embed soft skills through methods or models which could optimize success in developing soft skills of trainee teachers in Malaysia's Institute of Teachers Education. Therefore, this research will be guided by the following research questions: (1) Do lecturers have knowledge about soft skills? (2) Are lecturers prepared to embed soft skills in the core courses? (3) What are the impending problems faced by lecturers when embedding soft skills in the core courses? (4) What are the lecturers' recommendations to overcome problems encountered in embedding soft skills in the program courses?

\section{Problem Statement}

Various scopes of studies on soft skills have been conducted in Malaysia with the primary focus on general complaints about the level of soft skills of higher education institute graduates ( $\mathrm{Ng}$ et al., Shaharuddin et al.). However, at the same time, Ali et al., and Roselina [12] observed that it is usually difficult to observe, measure and evaluate soft skills. It is imperative to ensure acceptance and comprehension of soft skills by lecturers and trainee teachers so that the principles of soft skills can be applied by students in their whole life. Therefore, the

*Corresponding author: Norhasni Zainal Abiddin, Department of Professional Development and Continuing Education, Faculty of Educational Studies, University Putra Malaysia, 43400 UPM Serdang Selangor, Malaysia, Tel: 60193330065; E-mail: nonieza99@gmail.com

Received May 30, 2014; Accepted August 05, 2014; Published August 12, 2014

Citation: Hassan A, Maharoff M, Abiddin NZ (2014) The Readiness of Lecturers in Embedding Soft Skills in the Bachelor's Degree Program in Malaysia's Teachers Education Institute. Arts Social Sci J 5: 071. doi: 10.4172/2151-6200.1000071

Copyright: ( 2014 Hassan A, et al. This is an open-access article distributed under the terms of the Creative Commons Attribution License, which permits unrestricted use, distribution, and reproduction in any medium, provided the original author and source are credited. 
process of developing soft skills through formal teaching and learning activity is very significant to enable trainee teachers to develop their soft skills effectively.

The core courses basically focus on the required competencies that trainee teachers must have but there is no value added to trainee teachers from various fields. Even from the list of core courses listed, it is still not clear if soft skills is being taught as a stand-alone subject or as an embedded subject but the development of a set of soft skills for trainee teachers was clearly stated in the guidebook for the teachers' bachelor's degree course [13]. The total of credit allocated for core courses for the length of 8 semesters is 23 credits, a smaller credits compared to the 45 credits required for major courses. According to mastery of learning concept, the longer the length of student involvement in teaching and learning, the higher the mastery is towards certain knowledge. There is a possibility that the shorter the length of teaching and learning of core course, the lower the mastery of soft skills should be. In fact, Roselina [12] emphasized the difficulty of developing student soft skills because it is hard to measure the competency and the soft skills varies a lot among individual's character and their back ground.

It is challenging to develop trainee teachers' soft skills and the mastery concept in teaching and learning. Therefore, it is prudent that the aspect of lecturers' readiness to embed soft skills in core courses be analyzed to identify the aspects in which could directly affect developing soft skills within trainee.

\section{Materials and Methods}

This research is a case study with a small number of respondents from the same field [14]. This research is categorized as a tracing process [15], single case characteristics [16,17] and single example phenomenon study [18]. Eight respondents were involved in the study; they were lecturers who teach core courses in one of the teacher training institutes in Malaysia. Both quantitative and qualitative methods were combined in the pursuit of this research. The quantitative method was used to obtain data about the readiness of lecturers in embedding soft skills into core courses while the qualitative method was used to explore their problems and views about ways to overcome the problems.

Quantitative data were processed to obtain frequencies and percentages while qualitative data were processed to support the quantitative data. Qualitative data were collected through open questionnaire and serves as a data to support the quantitative data presented in this study.

The research instrument was designed based on the research questions. A set of questionnaire was distributed to respondents. These questionnaires were divided into three parts, namely Part A (centered on respondents' demography), Part B (focused on the lecturers' readiness to embedding soft skills into core courses) and Part C (problems faced by lecturers in embedding soft skills into core courses and the lecturers' views and suggestion on how to overcome these problems).

\section{Results}

\section{Respondent's profile}

This research involved 8 lecturers (three male and five female lecturers) who taught core courses. Table 1 illustrated that all the respondents have a master's degree as their highest academic qualification. In relations to teaching experience, only one respondent has between 11-15 years of teaching experience whilst seven others have more than 15 years teaching experience. Experience in teaching

\begin{tabular}{|l|l|c|}
\hline Details & Frequency \\
\hline \multirow{2}{*}{ Gender } & Male & 3 \\
& Female & 5 \\
\hline \multirow{2}{*}{ Highest academic qualification } & Bachelor's Degree & - \\
& Master's Degree & 8 \\
\hline \multirow{3}{*}{ Teaching Experience } & Doctor of Philosophy (PhD) & - \\
\hline \multirow{3}{*}{ Experience in teaching core courses } & $6-10$ years & - \\
& 6-10 years & 1 \\
\hline Number of courses about soft skill & Mone than 10 years & 7 \\
\hline attended & Less than 3 times & 3 \\
& More than 3 times & 4 \\
\hline
\end{tabular}

Table 1: Respondent's profile.

core courses for each respondent showed marked difference as three of the lecturers taught core courses between 1-5 years, four of them taught core courses between 6-10 years while one of the lecturers taught core courses more than 10 years. Moreover, Table 1 disclosed that only one of the respondents have attended a course on soft skills but less than three times, while another respondent have attended more than three times. Six other respondents have never attended any courses related to soft skills.

\section{Lecturer's readiness}

Table 2 shows that all respondents were interested in embedding soft skills in the core courses. Data indicates five of the respondents agreed strongly (62.5\%) and three respondents agree $(37.5 \%)$ with the statement that they are interested to embed soft skills in the core courses. Apart from that, all the respondents (100\%) agree that lecturers can help trainee teachers to develop their soft skills.

Subsequently, Table 2 indicates that three respondents agreed strongly while four others agreed with the statement that respondents feel confident to embed soft skills into core courses. Nonetheless, one respondent was not confident to embed soft skills into core courses. In other matters, $37.5 \%$ of respondents felt they were forced to understand soft skills for the purpose of embedding soft skills into core courses. On the other hand, $37.5 \%$ did not feel forced to understand soft skills while $25 \%$ were not sure if they felt forced to understand soft skills in order to embed soft skills into core courses. $25 \%$ of respondents also were not sure if embedding soft skills into core courses will be a burden to them while $75 \%$ did not agree that embedding soft skills into core courses will be a burden to them. If given a choice, $87.5 \%$ of respondents are interested to embed soft skills into core courses compared to one respondent who chose not to embed soft skills into core if given a chance to do so. As for readiness to embed soft skills into core courses, three respondents agreed strongly and four respondents agreed that in order to embed soft skills into core courses, initial setup will be required.

First research question: Do lecturers have knowledge about soft skills?

Based on respondents' profile, $75 \%$ of lecturers have never attended courses related to soft skills; this shows lecturers have no formal knowledge about soft skills.

Second research question: Are core courses lecturers ready to embed soft skills into core courses?

All the lecturers were interested to embed soft skills into core 


\begin{tabular}{|c|c|c|c|c|c|c|c|c|c|c|}
\hline Item & 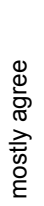 & $\%$ & 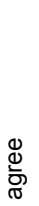 & $\%$ & $\begin{array}{l}\stackrel{0}{)} \\
\text { क } \\
\stackrel{0}{\circ}\end{array}$ & $\%$ & 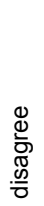 & $\%$ & 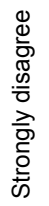 & $\%$ \\
\hline I am interested in embedding soft skills into core courses & 5 & 62.5 & 3 & 37.5 & - & - & - & - & - & - \\
\hline I can help trainee teachers to develop their soft skills & 3 & 37.5 & 5 & 62.5 & - & - & - & - & - & - \\
\hline I am confident to embed soft skills into the core courses & 3 & 37.5 & 4 & 50.0 & 1 & 12.5 & - & - & - & - \\
\hline I feel I was forced to understand and embedding soft skills & 3 & 37.5 & - & - & 2 & 25.0 & 2 & 25.0 & 1 & 12.5 \\
\hline Embedding soft skills into core courses become a burden to me & - & - & - & - & 2 & 25.0 & 5 & 62.5 & 1 & 12.5 \\
\hline $\begin{array}{l}\text { If given a choice, I do not want to embed soft skills inti core } \\
\text { courses }\end{array}$ & - & - & 1 & 12.5 & - & - & 6 & 75.0 & 1 & 12.5 \\
\hline Embedding soft skills into core courses requires initial setup & 3 & 37.5 & 4 & 50.0 & - & - & 1 & 12.5 & - & - \\
\hline
\end{tabular}

courses and have the desire to help trainee teachers to develop their soft skills. A majority of lecturers were confident in embedding soft skills and felt that it would not be a burden to them and states that initial preparation is required before embedding soft skills into core courses. In general, from seven items about readiness, six items clearly indicated that lecturers were ready to embed soft skills into the core courses.

Third research question: What impending problems will lecturers face in embedding soft skills into core courses?

In general, the open opinions from lecturers were categorized into following problems;

- The soft skills curriculum embedded into core courses might be similar to the human development program for trainee teachers or moral education or Islamic education. This situation makes them thinks that it is less important to embed the soft skills into core courses.

- Lecturers still do not understand soft skills, the method of embedding soft skills in the core courses and the efficacy indicators of soft skills

- Lecturers might lose focus on the teaching of core courses

- Students might not practice what they have learnt.

Fourth research question: What is lecturers'suggestion in overcoming problems associated with embedding soft skills into core courses?

Suggestions by respondents have been summarized as follows:

- Lecturers needs exposure and attending courses about soft skills

- Teaching and learning of soft skills must be done across the program curriculum and in the teaching and learning of core courses

- Soft skills embedding guidelines, execution and soft skills efficacy indicators in core courses must be prepared.

- Components in the soft skills must be clarified

\section{Conclusion}

\section{Lecturers' confidence in developing soft skills for trainee teachers}

Findings show that in general, lecturers are ready and confident to help in developing soft skills within trainee teachers through embedding soft skills into core courses but lecturers needs the support in form of knowledge about soft skills, knowledge about certain soft skills competencies (stated as components by respondents) and assurance that the soft skills that has been embedded into core courses do not overlap with the soft skills which might be similar in other courses such as those in the human development, moral education or Islamic education programs for trainee. This situation might have occurred because lecturers have no formal knowledge about soft skills which ideally should occur during each process of teaching and learning $[19,20]$. Nonetheless, there was anxiety among lecturers if they are unable to give focus to core courses when the soft skills is embedded into the core courses and the readiness of trainee teacher in learning soft skills. Anxieties might arise from confusion in using the teaching and learning approach that could embed soft skills and at the same time still did not lose focus on teaching and learning core courses.

\section{Teaching and learning approach that help in embedding soft skills}

All lecturers have provided suggestions to overcome the problems in embedding soft skills in the aspect of preparing the soft skills information to the lecturers and the teaching and learning approaches to embed soft skills. Although the idea of soft skills was introduced in the institute since 2006, it was adopted indirectly while teaching core courses, but what and how soft skills was adopted remains questionable because the research findings show that lecturers still seem to still require better explanations in terms of the components and competencies of soft skills as well as the instructional approaches that should be used to embed soft skills.

\section{Suggestion and implications}

Based on these preliminary studies, it is imperative that a research about how the soft skills being embedded in the teaching and learning of core courses be conducted to understand the views and philosophies of lecturers who embed soft skills into their core courses. At the same time, trainee teachers, as individuals who are themselves learning soft skills, have their own views and they are directly involved in the activity of learning soft skills where ultimately it will influence the process of developing soft skills. Therefore, the competencies which are required in core courses should be clarified so that no overlapping with other courses embedding the soft skills would happen. Consequently, it is also crucial to identify competencies for the said courses and a comparative study is conducted between different courses. Problems such as lack of knowledge about soft skills amongst lecturers can be resolved by providing training of soft skills formally to lecturers so that they can explore to be included in information about soft skills and give emphasis on the elements of soft skills core courses so that the soft 
Citation: Hassan A, Maharoff M, Abiddin NZ (2014) The Readiness of Lecturers in Embedding Soft Skills in the Bachelor's Degree Program in Malaysia's Teachers Education Institute. Arts Social Sci J 5: 071. doi: 10.4172/2151-6200.1000071

Page 4 of 4

skills development program for trainee teachers will be more clearly and easily followed.

\section{References}

1. Perreault $\mathrm{H}$ (2004) Business educators can take a leadership role in character education. Business Education Forum 59: 23-24.

2. James dan James (2004) Teaching career and technical skills in a "mini" business world. Business Education Forum 59: 39-41.

3. Mitchell GW, Skinner LB, White BJ (2010) Essential soft skills for success in the twenty-first century workforce as perceived by business educators. Delta $\mathrm{Pi}$ Epsilon Journal 52: 43-53.

4. Sutton N (2002) Why can't we all just get along? Computing Canada 16: 20-24.

5. Glenn JL (2008) The "new" customer service model: Customer advocate, company ambassador. Business Education Forum 62: 7-13.

6. Wilhelm WJ (2004) Determinants of moral reasoning: Academic factors gender, richness of life experiences and religious preferences. Delta Pi Epsilon Journal 46: 105-121.

7. Mohd Kamal Mohd Ali, Ab. Rahman Mahmud, Marzuk iNgah, Moh Rasid Chik Normar Ali (2005) Realiti dam miskonsepsi kualiti guru permulaan: analisis guru lepasan maktab perguruan Kuala Terengganu. Jurnal Penyelidikan.

8. Sidek M(2007) Isu-isu guru permulaan mengikut perspektif pengurus sekolah: satu refleksi di Institut Perguruan Sultan Mizan Besut, Terengganu. Seminar kebangsaan isu-isu pendidikan negara ketiga: Dasar dan pelaksanaan ke arah pengukuhan hala tujudasar pendidikan negara. Bangi, Selangor: Fakuti Pendidikan, Universiti Kebangsaan Malaysia.

9. Tamuri AH, Yusopp A, Osman K, Awaluddin S, Rahim ZAet al. (2004) Keberkesanan kaedah pengajaran \& pembelajaran Pendidikan Islam ke atas pembangunan diri pelajar. Putrajaya: Kementerian Pelajaran Malaysia.
10. Duki M(2004) Penilaianpelajarterhadapkepimpinan guru Pendidikan Islam kajian di daerah Kuala Selangor. Bangi, Selangor: Fakulti Pendidikan, Universiti Kebangsaan Malaysia.

11. Othman N, Mahamod Z, Ibrahim MS(2006) Kesediaanprofesionalisme guru novis: cadangan model latihan. Selangor: Universiti Kebangsaan Malaysia.

12. Shakir R (2009) Soft skills at Malaysian institute of higher learning. Asia Pacific Education Review 10: 309-315.

13. Guru BP (2009) BukuPanduan PISMP. Putrajaya: KementerianPelajaran Malaysia.

14. Yin RK (1994) Case study research: Design and methods. Newbury Park, CA: Sage.

15. George Alexander L, Andrew Bennet (2004) Case studies and theory development. Cambridge, MA: MIT Press.

16. Campbell Donald T, Stanley Julian (1963) Experimental and Quasiexperimental designs for reasearch. Houghton Mifflin, Boston.

17. Eckstein H (1992) "Case studies and theory in political Science" In regarding politics: Essays on political theory, stability and change. University of California Press, Berkeley.

18. Gerring J (2004) What is a case study and what is it good for. American Political Science Review 98: 341-354

19. Crebert G (2002) Institutional research into generic skills and graduate attributes: constraint and dilemmas. International Lifelong Learning Conference. Queensland.

20. Jones A (2009) Redisciplining generic attributes: the disciplinary context in focus. Studies in Higher Education 34: 85-100 